\title{
A study of Luke 10 in context
}

\author{
Ulrich Busse ${ }^{1}$ \\ University of Duisburg-Essen (Germany) \\ Research Associate: Department of New Testament Studies \\ University of Pretoria
}

\begin{abstract}
Chapter 10 in the center of Luke's Gospel serves as a good example by which the author's compositorial work directed at the reader can be illustrated. At the end of the sermon on the plain, Luke formulates his theological-practical maxim (6:46f): to hear and to do the Word of God. This is again illustrated in chapter 10 especially in the parable of the Good Samaritan and in the episode of Mary and Martha, in which instances reference is made to Stoic philosophy and ethics in a special way.
\end{abstract}

\section{INTRODUCTION}

As an excellent storytelling theologian, Luke embeds his intentions in the plot of his stories and his theology is not formulated in a way that is understood at a first glance. The so-called "travel-narrative" (sometimes referred to as "central section" in English) in particular may prove this particular narrative style. The counter reaction to this idea by $\mathrm{R}$ von Bendemann (2001), which had been part of the discussion about the synoptic question for some time at the beginning of $19^{\text {th }}$ century, again confronts one with the problems and especially with the central weakness of this Lukan unit of composition in the central section of his gospel (9:51-18, 14 as well as 19:44f). It has to be admitted that references related to travel are scattered throughout this section, although only few name the destination of Jesus' journey, namely Jerusalem (see $9: 51 ; 13: 33 ; 17: 11$ ). Therefore, for the most part the reader cannot directly recognise the intention of these references in their immediate contexts. From the start Mark and Luke represent Jesus as constantly walking in rural Palestine. Luke uses the much shorter Markan travel-section of Jesus' journey to Jerusalem (Mk 1:1ff), supplementing it with traditions from the

\footnotetext{
${ }^{1}$ Prof Dr Ulrich Busse is Professor of New Testament at the Universität Duisberg-Essen (Germany) and is a research associate of Prof Dr Jan G van der Watt, Department of New Testament Studies, Faculty of Theology, University of Pretoria. The German version of this essay was published in M Fassnacht et al (Hrsg) 2003, Die Weisheit - Ursprünge und Rezeption: F S Karl Löning, 139-153. Münster (NTA.NF 44.) and is republished in a revised form.
} 
Saying Source Q and from his own special traditions. He changes these narratives to didactic lessons, which have no reference to the final destination of Jesus' journey anymore (See McCown 1938:51-66; Flender 1965:71; Schneider 1958:218; Gill 1970:206 n 16).

This way of reworking also applies to chapter 10. After the short but formal note in 9:51: "As the time approached when he was to be taken up to heaven, he set his face resolutely towards Jerusalem", Jesus sends some of his disciples to an unspecified Samaritan village. However, shortly afterwards (10:1) he appoints 72 or 70 disciples and sends them off in pairs to every town and place which he himself intends to visit. In this way his formerly expressed intention of travelling to Jerusalem seems to disappear in chapter 10. In addition to this odd development of the plot, the imagery of the parable of the Good Samaritan (10:30-37) reflects ancient travel language; the hapax legomenon - "to travel" ( $\mathrm{v} 33$ ) - provides the first modest indication of a journey, in addition to the reference to the "first aid kit" of the Samaritan. Thirdly, there is the reference to the inn, which mirrors the Roman imperial traffic-system (Reed 2000:146-148), more than Judean reality, and finally at the end of the chapter the wandering Jesus visits the house of the two women (10:38). No mention is made of his already pre-determined destination, Jerusalem.

In order to understand the intention behind the composition, it is worth studying the first three verses of chapter 10 . Clearly the first verse points back to 9:52, where Jesus, in a far more modest framework than in 10:1, had sent messengers ahead into a Samaritan village. The inhabitants of this village did not want to welcome him, because he was on his way to Jerusalem and the Jewish temple and not to Garizim, the temple mount of the Samaritan people. Therefore, most interpreters regard the numbers 70 or $72^{3}$ as symbolic, referring to the universal and global post-Easter mission (see Ac 1:8). Related to this perspective Jesus is generally addressed as Kurios or "master" in this chapter, a form of address that is reserved for God and the resurrected Christ in Luke-Acts.

Jesus' admonition in verse 3 , namely that he has to send his disciples "like sheep under wolves," corresponds with the post-Easter experience of his

\footnotetext{
${ }^{2}$ In antiquity Hippocrates advised travellers to carry wine and oil as medicine (See Wettstein, 1752, volume I; Cadbury (1933:62).

${ }^{3}$ The conflicting versions reading 70 versus 72 in Luke 10,1 have a reference to the biblical and early-Jewish literature, which could explain the difference. The number 70 reminds of the seventy translators of the Hebrew Bible in Greek (LXX) and is reminiscent of the seventy elders in Exodus 24:1, 9. Together with Moses they ascended Mount Sinai. Each tribe of Israel was represented by six people, thereby arriving at the sum of 72 (see Jos, Ant 12.57). In Enoch 89:59 seventy shepherds of Israel are mentioned. However, in 90:1 half of them, namely thirty-six are counted, again totalling 72 . Therefore, both references metaphorically point to the future task of the disciples to announce the Word of God to all people in the world in the language of the time.
} 
first readers. The Q-tradition also fits this trend set by the evangelist, who thereby enriches the social perceptions as well as the experience with individual people of the first travelling missionaries. They used the greeting shalom as codeword to signal their peaceful intents, with the ultimate idea of reaching entire cities with their missionary work. Surely this does not reflect the historic reality in the times of Jesus, nor for many years after his death, although it might have been the case for the first readers. By collectively contrasting Tyros and Sidon in this framework with Bethsaida, Chorazin and Capernaum ( $v$ 13f), allusions seem to be to the future. ${ }^{4}$ These vivid memories indicating disapproval appear to have been inserted to document the repeated rejection of the good news of Jesus and his later messengers by these Galilean "cities". The motif of refusal appears not only in 9:52f, but is generalised here and at the same time dialectically turned around. Now, only the Good Samaritan, and not the temple staff in Jerusalem, displays the correct behaviour. Therefore, it comes as no surprise that Jesus (9:18-24) had spoken to his disciples about his divine legitimation and the revelation thereof during Easter. These few observations already let us suspect that this chapter was not written for the sake of portraying past events related to the time of Jesus, but rather for the sake of the later first readers. Is the intention perhaps that the reader should discover himself as part of the narrative and consequently responds to it?

\section{HAPPINESS LIES MORE IN GIVING THAN IN RECEIVING}

The so-called "travel-narrative" contains fifteen similes that fit Luke's particular intention to instruct his readers. Because almost all of them are introduced by a specific formula, which was only used once before, two types are clearly distinguishable. The first type is introduced by the question: "Which of you ...?" $(11: 5 ; 14: 28,31 ; 15: 8 ; 17: 7)$, while the other, generalising the narrative, opens with "(There was) a man ..." (10:30; 12:16; 13:6; 15:11; 16:1, 19; 18:2, 9 ; see $7: 41$ ). Only one formula of introduction (14:8ff) cannot be classified with certainty because, in that given context the guests have to be addressed directly. However, a possible classification of this formula tends more to the first type.

In this way, all similes serve the reader-instruction more than they do the plot, although the first impression would suggest that Jesus is speaking in a concretely historic scenario and situation. Nevertheless, it is recognisable that Luke wants the reader to study certain typical situations in order to get to know a specific aspect of Jesus' experiences as expressed in his parables.

\footnotetext{
${ }^{4}$ As his miracles indicate, Jesus himself was rather successful in these Galilean villages. These words against Chorazin, Betsaida and Capernaum are thus all the more surprising. Therefore, it seems more plausible that they were generated in a second mission phase after Easter. During that phase the charismatic missionaries had renewed Jesus' mission to Israel.
} 
Each simile represents an instructive example for their Christian conduct and living.

Of the 15 similes, four are clear illustration-stories, a form, which perfectly complies with the Lukan intention. All four open with a question directed to Jesus (10:25-29; 12:13-15; see 16:14 with 16:10ff; 18:9-14). In our context Jesus is asked a question about the highest commandment, a text originally from Mark 12:28-34. Luke removed it from its original context in order to introduce his illustration-story.

Therefore, compared to Mark 12, the first part of the pericope - which runs parallel to Mark 12 - is missing from Luke 20. But in the crossing from Luke 20:34-38 to 20:41ff, with verses 39-40 in the middle, it is still obvious that the evangelist must have been completely familiar with the original context of the pericope. Therefore, the hypothesis that Luke has taken 10:25-28 from a special source or even from the Saying Source Q, is impossible. Furthermore, Luke avoids disputes in his passion-story. This represents an additional reason for him to take the pericope out of its original context and to utilise it in a new setting. If the Markan origin of the verses is secured, then the verbal differences in the quest for the highest commandment will be especially interesting.

In this case and in contrast to the original Markan text, a "Torahlawyer", and not a "scribe", puts the question to Jesus - this slight difference is meaningful. In view of 11:45ff a "Torah-lawyer" has a bad reputation because of the serious mistakes of his predecessors. They were namely accused of repeatedly having killed the prophets sent by God. In the present context, they hide "the keys of knowledge" (11:52), that is to say, they hide the Bible, the extraordinary book, which people normally study to discover the will of God. In this gospel both the Torah-lawyers and the Pharisees are pictured as being ethically corrupt, rejecting God's purpose for their own sake (compare 7:30; 11:39-44 with 16:14f).

Rather unexpectedly for the reader, a person belonging to this group appears on stage and poses the question about the way to eternal life (compare 18:18 with 3:10-14). In Mark this question is of a purely theoretical nature. It follows straight after the exact wording of the first commandment. Here, however, it is posed with an evil intent. But Jesus leaves him who asked to answer his own question. In his answer the lawyer correctly quoted the Bible (i e Dt 6:5; Lev 19:18) but the monotheistic confession at the beginning is omitted, although still quoted in the Markan form. However, the omission allows Luke to reformulate Jesus' answer: "Do that, and you will have life" (v 28). The Lukan Jesus is not actually interested in the original wording of the first commandment but is more concerned about translating it into practice, namely that only it grants eternal life. By putting the commandment into practice Jesus and the lawyer apparently agreed about the true way to 
salvation: In the perspective of the Lukan Jesus, acting is more important than knowing and reciting the Decalogue. But the questioner is not yet satisfied. His ensuing question is aimed at Jesus' concept of the person "near" (not "next" to) to someone.

The particular way in which the question is formulated already and in an indirect way paves the way for the illustration to follow. The lawyer's enquiry is more general than one would have expected from a Jew in the first century. During that time the common opinion was that the person next to me would always be a Jewish countryman. But in this instance the question is more broadly put: who is "near" to me?

In order to demonstrate what is meant by "near" Jesus illustrates his particular view in the following well-known story. The correct answer becomes apparent by studying the three different reactions to the emergency that arose in the desert en route to Jericho: First a priest and then a Levite, both representing Jewish temple personnel, ${ }^{5}$ passed by a man who was brutally attacked and robbed. The robbers had beaten him half dead and left him seriously injured. In the third instance a Samaritan, the religious rivals of the Jews, which was already stated in 9:52, saw the badly injured man in this alarming state and immediately came to his rescue. The story now focuses on the deeds and behaviour of the Samaritan and abstains from reasoning about the priest's and Levite's failure to act.

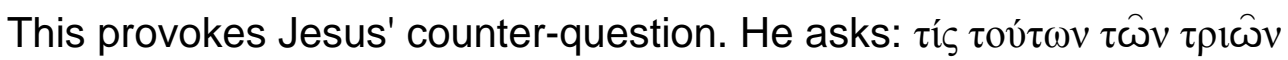

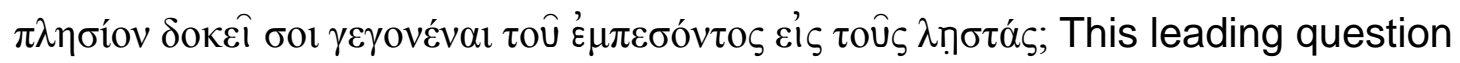
leaves the questioner with only possible answer: the Samaritan. He was the one who was determined to be close to the injured man. Jesus completes his answer - implicit in the story - with a challenge to act like the Samaritan.

The emphasis on actions refers back to both verses 28 and 25. Again, the second part of the first commandment only achieves its relevance when applied to active life, in other words, in a manner such as had been demonstrated by the exemplary conduct of the Samaritan. He showed sensitivity for situations in human life, in which the right of self-realisation obtains a deeper meaning. One does justice to oneself not only when catastrophes create the opportunity for helping others, but also when one comes close to a fellow human being who finds himself in an alarming situation, being determined to be his 'nearest' by putting all one's abilities at his disposal.

\footnotetext{
${ }^{5}$ Priests and Levites, who lived on the temple, were promised in T Levi 2 that "the Lord himself becomes your field, grapevine, fruits, gold and silver." Their activities were aimed at the maintenance of the temple functions. In what way ethical performance in everyday life was demanded, remains an open question (see 1 QS IV:4).
} 
The parable is obviously directed at the reader. Again Luke focuses on correct behaviour and actions ${ }^{6}-$ it is this social commitment that leads to an everlasting life with God. Moreover, in this regard verse 35 widens the scope of the original parable. This verse seems to be superfluous given the overall goal of the plot. However, anybody with knowledge of Luke's redactional tendency will recognize his emphasis on the proper way of dealing with wealth and money (see Cadbury 1927:260). In this verse Luke illustrates how in the case of emergency one can contribute by means of what one has. Ultimately, the Samaritan had paid for the expenses associated with the care of the injured person without expecting repayment (compare 6:35). Instead, he gave an undertaking to the host to settle the bill in respect of the remainder of the nursing fees upon his return from the business trip. Later on behaviour of this nature in financial matters is also confirmed in Acts 20:35. ${ }^{7}$ Here Paul reminds the congregation as follows, "All along I showed you that it is our duty to help the weak in this way by hard work, and that we should keep in mind the words of our Lord Jesus, who himself said, 'Happiness lies more in giving than in receiving." Not only did the Samaritan not pass the seriously injured by, but he also gave him further assistance. In this way, he provides an excellent illustration of what constitutes desired Christian behaviour, especially in contrast to the parable of the rich man in 16:19ff, who leaves the poor and suffering Lazarus outside his house, refusing any assistance.

\section{EPISODES TOLD IN A DIALECTICAL WAY}

In full agreement with the Lukan tendency of educating through narratives, another literary advice is used in the following pericope. On his tireless mission of proclaiming the word of God, Jesus stops at a house in an unnamed village where two sisters live. By changing the perspective, this episode is told in a dialectical way. At the beginning of chapter 10 the disciples' mission is narrated from Jesus' perspective. He sends them out. It is their responsibility to obtain accommodation in foreign houses but more often than not, they are turned away, as Jesus had predicted. However, sometimes they are invited in and it is precisely for this purpose that Jesus earlier had taught them, "let your first words be: Peace to this house. If there is a man of peace there, your peace will rest on him; if not it will return to you. Stay in that house, sharing their food and drink." Now, a similar situation is narrated but from the perspective of the inhabitants, who apparently have invited Jesus in to eat and to drink with them.

\footnotetext{
${ }^{6}$ Observe the frequent application of the verb "to do" in verses 25 and 28 (diff Mk) and 37; in the latter case it is even used twice.

${ }^{7}$ See Acts 9:36, 39, too. Again reference is made to "doing acts of mercy".
} 
The well-known Lukan introductory formula is again used, this time in the form of "a woman named Martha ..." (cf "a man was on his way ..." v 30). Again the perspective is exemplary and at the same time dialectical. Martha's behaviour is compared with that of her sister, who sits at the feet of Jesus listening to him. The important difference in the reaction of the sisters is also linguistically highlighted. The first verse is formulated in the normal narrative tense (aorist), but in the subsequent one and a half verses it changes to the present tense, which continues to be the case until Martha asks Jesus to intervene in her favour. In verse $40 \mathrm{~b}-42$ the dispute is settled and the narrative diverts back to the aorist.

Martha, who as hostess first received Jesus, tries hard to be a proper hostess (v 40), while her sister Mary ( $v$ 39) sits at the feet of Jesus to hear "his word", that is God's word (cf 5:1 with 4:43; 8:11, 21; 11:28 among others). This, in Martha's view, is being idle. In 4:43 God's word has already been defined as "the gospel of God's reign", which has to be announced by Jesus all over the Jewish countryside. In this way it is demonstrated that Jesus was not interested in the intended role of guest of honour, but rather to bring his central message to the home of the two sisters as well. Therefore, the small note, to the effect that Mary sat at the feet of Jesus, indicates that she as his pupil attentively listened to Jesus' words. In this way she anxiously wants to take in everything (cf Ac 22:3; PAvot 1.4). ${ }^{8}$ Her behaviour shows that Jesus had female disciples too (cf 8, 20f).

Martha, however, is characterised ( $v 40 f)$ by three particular verbs: "distracted by many tasks", "to be worried" and "being troubled about many things". Since the time of Polybios, ${ }^{9}$ the famous Greek historian, the first verb had a negative meaning of "distract from the main point" (cf 1 Cor 7:34). The second verb "to be worried" is even more strongly accentuated by Luke. Already in 8:14 Luke changed the Markan presentation (Mk 4:19) to clarify his position by replacing the phrase "remaining desires" with "to be worried about the pleasures of life". In Greek this implies "sexual desire". ${ }^{10}$ Luke presents his view in an even more radical way in 21:34: "Be on your guard; do not let your minds be dulled by dissipation and drunkenness and "worldly cares", in other words, sexual hyperactivity, "so that the great day catches you suddenly like a trap". This verb is also used four times in $\mathrm{Q}(12: 11,22,25 f)$ in this negative sense, where the first two uses negate anxiety while the remaining two declares the impossibility of being able to extend life by worrying: "Can

\footnotetext{
${ }^{8}$ See Sueton, Claudius 32 and Valerius max II.1, too.

${ }^{9}$ Polybios 4.10.3; 15.3.4; 3.105.1 (see Diod Sic 2.29.5; Epictete 3.9.19; Jos, Ant 5.1; Bell 1.232; POxy 743.36; PTebt 37.15.

${ }^{10}$ In Acts 24, 25 the Lukan Paul can admonish the Roman procurator Felix to abstain from obsessive sexual desire.
} 
anxious thought add a day to your life? If, then, you cannot do even a very little thing, why worry about the rest"? Therefore, the evangelist uses our story to illustrate his position, which he has acquired from his Jesus' tradition. Obviously he describes a way of life in which human beings become lost in permanent worry about everyday activities in this world. Continuing in the same vein, he comments on it by the last verb used in this section "to be extremely restless". A man, who "is in unrest about much", probably misses the true essentials of his life. This is how Martha is characterised by Luke.

However, Martha's behaviour is compared to those of her sister Mary. In his intervention at the end of the episode, Jesus explains his viewpoint. He, too, contrasts her worries with the behaviour of the disciple Mary (v 42). Martha is "worried and in unrest about much" ( $v 40,41 b)$ while the other knows, that "only one thing is really necessary" (compare v 40, 41b/42) during his special presence in the house: to listen to God's word. A person who arranges her life in the same way Martha does, is manipulated by others. She does not live her own life, but other things determine her life. However, everybody who hears the word of God has chosen the "only best", ${ }^{11}$ which shall not be taken from him or her (cf 12:25-31), because those who listen to God's word and consider it as the only true orientation for their lives, attain a "treasure in heaven" (12:33; cf 10:20b; 12:21; 18:18ff, particularly v 22, 30). This "best part" cannot be taken from him or her. Therefore, the behaviour one chooses remains significant until the last judgment. It is with this perspective in vers $42 \mathrm{~b}$ that the evangelist concludes his moral lesson directed at the reader.

\section{LUKE'S AND EPICTETE'S ETHICS}

The above episode mirrors the domestic way of life in a village where two sisters with contrasting behavioural patterns find themselves in an environment that can be labelled as "bourgeois" and that seemingly lacks the total dedication of Jesus' first followers (cf 9:3$4: 57-62 ; 10: 4-5)$. This point Luke tries to convey to his readers who are living under new conditions in the Hellenistic world. As background to this pericope Jesus uses popular ethics, which were shaped during Hellenistic-Roman times by the Cynics and the Stoa.

The contrast between "one" and "many", which has dominated the characterisation of the ladies, is also found in Epictete's Dissertationes 1.1.14:

But now, although it is in our power to care for one thing only and devote ourselves to but one, we choose rather to care for many things, and to be tied fast to many, even to our own body and our estate (cf Lc 12, 13ff) and brother and friend and child and slave (cf

\footnotetext{
${ }^{11}$ See Plutarch, Isis \& Osiris 370c.
} 
Lc 9, 59-62; 14, 26ff; 18, 18ff). Therefore, being tied fast to many things, we are burdened and dragged down by them.

[all translations are taken from the Loeb Classical Library]

The same author expresses the conviction that one can become distracted from the most important thing by being involved in too many other things (see Epictete, Diss $1.29 .59 ; 2.21 .22)$. In 3:22.69 of his Dissertationes he writes:

But in such an order of things as the present, which is like a battlefield, it is a question, perhaps, if the Cynic ought not to be free from distraction, wholly devoted to the service of God, free to go about among men, not tied down by the private duties of men, nor involved in relationship which he cannot violate and still maintain his role as a good and excellent man, whereas on the other hand, if he observes them, he will destroy the messenger, the scout, the herald of the gods, that he is. For see, he must show certain services to his father-in-law to the rest of his wife's relatives, to his wife herself, finally, he is driven from his profession, to act as a nurse in his own family and provide for them. To make a long story short, he must get a kettle to heat water for the baby, for washing it in a bath-tub; wool for his wife when she had had a child, oil, a cot, a cup (the vessels get more and more numerous); not to speak of the rest of his business, and his distraction.

Dio Chrysostomos $($ Or 13, 13) expresses himself even clearer on the causes of the all consuming stress of the human being:

\begin{abstract}
And the opinion I had was that pretty well all men are fools and no one does any of the things he should do, or considers how to rid himself of the evils that beset him and of his great ignorance and confusion of mind, so as to live a more virtuous and better life; but that they are all being thrown into confusion and are swept round and round and round in the same place and almost practically the same objects, to wit, money and reputation and sexual pleasures of the body, while no one is able to rid himself of these and set his own soul free; just as, I fancy, things that get into a whirlpool are tossed and rolled without being able to free themselves from the whirling.
\end{abstract}

This comparison between selected citations and the moral idea conveyed in this Gospel reveals a clear relationship between them. The contemporaries of the New Testament writers, acting as philosophical "pastors" and advisors in questions of life, offered a similar maxim as had Luke: Rather concentrate on a single essential matter than worrying about too many things. There is much commonality between Luke and his contemporaries concerning their description of a person whose attention is diverted by too much business and 
temporal fear. The catalogue of vices of the popular ethics in Hellenistic philosophy and in that of Luke is easily paralleled without much difficulty.

However, as far as the description of the positive side, in other words, the meaning of life, is concerned there are significant differences between the two philosophies. In particular, the Lukan episode is guided by interests that differ from Epictete's admonitions. Mary has chosen the good part that is immortal that cannot be lost?

In this episode the evangelist conveys his message on proper behaviour in such a way that it is established as the center of his ethical conception: Everybody who has come to know the right behaviour by hearing and doing Jesus' words and who furthermore translates these words into actions on a daily basis, will be kept protected in heaven (cf 10:20), even in the eschatological judgement, where this behaviour will come to his or her defence.

\section{A "BOW OF TENSION" AS CONCLUSION}

Luke abandoned the Q-tradition in favour of self-developed narratives. It is evident in the following. Uncovering the parallel between Luke's view of a successful life (directing one's life towards salvation) and similar views of the Hellenistic philosophers, underlines Luke's ability to adapt his message to a Hellenistic environment. He does this in accordance with the Jesus tradition. $\mathrm{He}$ also radicalises the first commandment by withdrawing it from human manipulation. Greek idiom was also detected in the Lukan text. It therefore remains advisable to read the individual events and actions in the light of the broader context.

If one does not want to settle for the idea that Luke simply presented us with a chain of rather unrelated historical events without an evident common denominator, one must look for deeper meaning. Historical-critical interpreters were aware of this problem, but resolved it with the conviction that in the "travel narrative" Jesus was interested in teaching his disciples a vita Christiana. However, R von Bendemann recently pointed another way. He convincingly demonstrated that on a narratological level a "bow of tension"' is created between 8:1 and 10:42 aimed at the reader. This highlights an important shift in critical research from the view that this text was written as instruction to the disciples to the conviction that it was written as instruction to the reader.

Departing from this point of view, the reader can easily detect the skilful and playful composition of the author aimed at illustrating the consequences not only of Jesus' call of Peter to become a fisher of men (5:1-10) (see Busse 2005:113-129), but also of calling the twelve (6:12-16), and with them opening the way for the mission of all future Christians (10:1ff). The reader is presented with both parts of the game: that of the sent missionaries, as well 
as that of those who invite them into their houses. This way of Christian mission is not without its challenges, failure or danger for both sides. From the reader's perspective Jesus is the central figure and main referee, who comments on the values of the game from his superior perspective and in this way encourages the reader. But Luke also deals with the historical distance between Jesus and the readers by cautiously adapting the message to his own cultural environment and to that of his readers.

The harmony of composition and content applies to 10:25-42, too: Here Luke answers the question: What do the words of Jesus in 6:47 mean for his own time? "Everyone, that comes to me and hears my words and acts on them, - I will show you what he is like": On the one hand, it echoes Mary who has chosen the best part, that part which nobody can take from her. On the other hand he echoes the Good Samaritan, who has followed "the word" in its fullest sense. Typical of the narrative of Luke the presentation remains dialectical. On the level of the implicit author and reader the composition is understandable while its historic dimension is clearly retained.

\section{Works consulted}

Von Bendemann, R 2001. Zwischen $\triangle \mathrm{O} \Xi \mathrm{A}$ und $\Sigma T A Y P O \Sigma$ : Eine exegetische Untersuchung der Texte des sogenannten Reiseberichts im Lukasevangelium, Berlin: Walter De Gruyter. (BZNW 101.)

Busse, U 2005. Begegnung mit dem Wort nach Luke 5, 1-11: FS A Denaux, 113-129. Leuven: Peeters. (BEThL 182.)

Cadbury, H J 1927. The making of Luke-Acts. London: SPCK.

Cadbury, H J 1933. Lexical notes on Luke-Acts V: Luke and the horse-doctors. JBL $52,55-65$.

Fassnacht, M et al (Hrsg) 2003. Die Weisheit: Ursprünge und Rezeption: FS Karl Löning, 139-153. Münster: Aschendorff. (NTA, NF 44.)

Flender, H 1965. Heil und Geschichte in der Theologie des Lukas, München. (BEvTh 41.)

Gill, D W 1970. Observations on the Lukan travel narrative and some related passages. HThR 63, 199-221.

Mc Cown, J J 1938. The geography of Luke's central section. JBL 57, 51-66.

Reed, J L 2000. Archaeology and the Galilean Jesus, Harrisburg, PA: Trinity Press International.

Schneider, J 1958. Zur Analyse des lukanischen Reiseberichtes: FS A Wickenhauser, 207-229. München.

Wettstein, J 1752. Novum Testamentum Graecum, 2 vol. Graz: Akademische Verlag. 